\title{
The Social Policy Responses of the Chilean State to the Earthquake and Tsunami of 2010
}

\author{
Kirsten Sehnbruch \\ Nurjk Agloni \\ Walter Imilan \\ Claudia Sanhueza
}

\begin{abstract}
This paper examines the capacity of the Chilean state to respond to the social impact of the 2010 earthquake and tsunami in the context of the recommendations made by the international literature on natural disasters. We examine the impact of the earthquake on social variables, including housing, health and education using a dedicated panel survey data. Decades of neoliberal policy have left Chile with a skeletal state, which largely administers social policy through targeted and very narrowly focused social programmes. The reconstruction effort of the Chilean state largely responded to the emergency through these same targeted social policy allocation mechanisms. While official reports on the reconstruction effort show a state that is complying with its specified goals, evidence from qualitative fieldwork undertaken in the city of Constitución illustrates the extent to which this method proved to be highly inadequate in the context of a natural disaster. We conclude by arguing that Chile should establish a social policy structure for natural disasters that allows for a rapid response to a social emergency based on universal or near universal allocation criteria.
\end{abstract}

Key Words: Chile, Earthquake and tsunami 2010, public policy for disasters, emergency, reconstruction.

\section{Introduction}


Most accounts of the Chilean earthquake of 2010 begin with an enumeration of the losses that it caused: the number of lives lost, the percentage of housing lost, and the economic cost of the earthquake (CEPAL 2010a; Gobierno de Chile 2011 y 2012; Larrañaga \& Herrera, 2010). Analysts argue that Chile's material infrastructure withstood the earthquake so well because decades of work on building codes and their enforcement have led to earthquake safe constructions (Cámara Chilena de la Construcción, 2010; Bitar, 2010). In addition, experts highlight the rapid response of the Chilean government to the emergency situation: within one day the country's national highway was reconnected so that supplies could be moved up and down the country. Similarly, the international airport, which had also been damaged, was operational again within one day to the extent that commercial flights resumed after only three days. Despite the initial breakdown suffered by Chile's telecommunications network, which severely hampered the government's response capacity, communications were also re-established rapidly, as were electricity and water supplies. ${ }^{1}$

By comparison, the social consequences of the earthquake have been studied very little. Questions such as whether the earthquake affected poorer and middle class families more than higher income households have not yet been analysed in depth. Similarly, changes in employment and labour market participation patterns as well as the increase in poverty levels have not been focused on. This article therefore asks two central questions: first, what was the impact of the earthquake on Chile's social indicators? Second, was Chile's social policy infrastructure equipped to deal with the scale of the disaster?

It is extremely important to ask these questions in the context of the fact that decades of neoliberal policy have left Chile with a skeletal state, which largely administers social policy through targeted and very narrowly focused social programmes (Borzutzky, 2002; Solimano, 2012; and Atria et al, 2013). This means that housing, health, education, employment and income support are only assigned to people who meet a defined "poverty criteria", and who are considered to be "vulnerable". ${ }^{2}$ The problem with this approach is that families are judged by quantitative measures and not by the multiple qualitative dimensions that define not only poverty, but also vulnerability. In the case of a natural disaster, both the poor and the non-poor population are affected. What matters therefore is the overall concept of

\footnotetext{
${ }^{1}$ See Kovacs (2010) and the American Red Cross (2011) for favourable evaluations of Chile's system of emergency response.

${ }^{2}$ A description of the policy instrument used to define who is poor and eligible for a subsidy can be found in Herrera et al. (2010).
} 
vulnerability and the capability that each family has to overcome the effects of the natural disaster (Davis, 1996). In addition, we should note the earthquake and tsunami hit regions that are weaker than the Chilean average in terms of their socio-economic indicators, and therefore also less well equipped for dealing with the consequences of a natural disaster (CEPAL, 2010 and 2010b). ${ }^{3}$

The lessons that we can learn from questioning the appropriateness of Chile's social policy structures in general, but specifically for dealing with a natural disaster, are crucial to the country's preparation for future socio-natural disasters. In the same way that historic experiences of disaster made Chile think about improving its earthquake resistant building codes and construction techniques, the country also needs to develop institutional infrastructure and response mechanisms that can deal with the social emergencies of earthquakes and other natural disasters, which can be just as devastating as their material aspect. ${ }^{4}$

In this context, we must, of course, consider that there is a significant overlap between the material damage caused by earthquakes and the social dimension. One of the biggest problems after the 2010 earthquake in Chile was the damage suffered by housing, which is one dimension of social policy. For example, in the six affected regions, $8.8 \%$ of the population suffered damage to their homes or lost them completely. This impact was bigger in low-income households, $12 \%$ for the poorest quintile, because of the precarious quality of their houses and because of their location (Larrañaga, O. \& Herrera, R., 2010). The key concern here is that reconstruction subsidies and benefits are also allocated according to the same point scores that determine access to other social benefits such as income support, and are therefore subject to the same narrow and highly focused criteria. In addition, reconstruction subsidies for housing were allocated according to the same criteria according to which social housing is normally allocated, without any modification of the programmes to the specific conditions generated by the earthquake.

\footnotetext{
${ }^{3}$ An analysis of the possible macroeconomic effects of natural disasters indicates that these effects are more significant at the regional and local level, even if this is not reflected by a country's average macroeconomic indicators (Cavallo y Noy, 2009; Noy, 2009; Dore y Etkin, 2000; Hochrainer, 2009; Raddatz, 2009). In addition, the international evidence that natural disasters have negative long-term effects which affect a country's productive capacities, its aggregate demand, and physical capabilities (Albala-Bertrand, 1993; Toya y Skidmore, 2007; Rasmussen, 2004; Hochrainer, 2009). These effects are stronger in smaller countries such as Chile, but can be mitigated by a favourable institutional environment (Jaramillo, 2009).
}

${ }^{4}$ See Hoffman and Oliver-Smith (2002). 
This paper is based on the revision of academic and institutional literature on natural disasters and on the role of the state in this context. We relate this literature to the Chilean case and to the empirical evidence available on the impact of the earthquake and tsunami using data from the 2010 household survey, which was specifically designed to capture its impact. In addition, we relate it to the fieldwork that we undertook during 2013 in the city of Constitución, where we interviewed civil servants at all levels of the public administration (municipal, regional, and central government) who were involved in the distribution of social benefits to families affected by the earthquake as well as local residents, who were affected by the earthquake and therefore had to deal with the procedures through which benefits were allocated. ${ }^{5}$ This combination of interviews allowed us to gage the ability of the Chilean government to respond to the social emergency created by the earthquake.

This article hopes to contribute to the existing literature on the Chilean earthquake by combining the analysis of qualitative interviews with the limited statistics available. The paper proceeds as follows: the following section discusses the international literature on natural disasters and how it relates to Chile. We then provide an overview of the impact of the earthquake on social indicators. The following section of the paper presents an analysis of our fieldwork undertaken. We conclude by arguing that Chile lacks an established protocol as well as a social policy infrastructure for dealing with natural disasters. We therefore recommend that such an infrastructure should be established to enable a rapid response to social emergencies based on universal or near universal allocation criteria in the future.

\section{The Role of the State and its Institutions in Dealing with Natural Disasters}

To begin with we must consider the fact that most countries are ill-prepared for dealing with the traumatic and destructive consequences of natural disasters. This fact is true for both developed and underdeveloped countries, but especially for underdeveloped ones. Governments generally do not prioritise policies that prepare for potential natural disasters, and tend to respond only when circumstances force them into action. After a catastrophe, public and political attention focuses on the

\footnotetext{
${ }^{5}$ Details on the interviews and focus groups carried out can be found at the end of the bibliography. They were carried out during August and September 2013 by members of the Observatorio de la Reconstrucción and the Centro de Investigación de Vulnerabilidades y Desastres Socionaturales (CIVDES) both at the Universidad de Chile. The principal objective of the fieldwork was to reconstruct the emergency response and reconstruction process that followed the earthquake in the city of Constitución, to identify critical junctures in these processes, as well is experiences of collaboration and conflict within the city.
} 
mitigation of damages as well as on supporting victims, who acquire a protagonistic role in the media. This interest in the disaster and its victims gradually declines in the period following the disaster and governments return to the "politics as usual" until the next disaster happens (Birkland, 1996).

This process also means that planning for potential disasters is often relegated to the backburner. This vicious circle is compounded by the fact that governments get little political credit for preventing a disaster. In addition, the benefits of having planned an effective response for a natural disaster accrue to future governments, and not to those politicians who instituted such a response. However, once a disaster occurs, political credit depends on how well a government responds to it (UN, 2002; Pelham et al. 2011).

The international literature has reviewed the experience of different countries with natural disasters and has reached a certain consensus about which policies are useful in the prevention of these disasters. The literature discusses many different ways of dealing with the emergencies of natural disasters, depending, for example, on the socio-economic context of the country, its geographic conditions, and its level of institutional development. However, it does come to some degree of consensus on some key issues:

The first is the need to establish risk management systems prior to an emergency occurring. This allows policymakers to evaluate and plan response actions before a natural disaster occurs. These emergency systems have to be integrated, both amongst each other and with local capacities in the areas of finance, administration, and technical support to (Vakis, 2006). As we will see in this paper, while the Chilean government has established a basic infrastructure for dealing with natural disasters (such as the establishment of a national agency for emergencies, the Oficina Nacional de Emergencia del Ministerio del Interior y Seguridad Pública, ONEMI), Chile does not have an established infrastructure for the management of risk. The ONEMI is an agency with very limited resources, a limited capacity to coordinate risk prevention programs, and no institutional mandate to manage a reconstruction process. ${ }^{6}$ The ONEMI's capacities concentrate principally on organising the emergency response to natural disasters. $^{7}$

\footnotetext{
${ }^{6}$ See Vargas (2002) for recommendations on the different stages of risk prevention.

${ }^{7}$ Historically, the Corporación de Fomento y Reconstrucción (CORFO) was charged with in reconstruction issues after the 1939 Chillán earthquake. However, CORFO's mission has since expanded to broader development issues, which has led to the neglect of reconstruction policies.
} 
The Cepal (2010b) suggests a risk management model that considers and systematises five fundamental aspects: risk assessment, mitigation, better preparation for emergencies, the strengthening of institutions, and financing. In this paper, we will argue that the response of the Chilean government to the emergency was extremely ad hoc, especially with regard to its social policy responses, particularly as they relate to the most vulnerable segments of the population.

This is an important aspect of the disaster that must be analysed because even when natural disasters affect a whole geographic area, the people most affected by them will be low income households, especially in less developed countries, where they are generally more exposed to natural disasters through the location and quality of their housing. At the same time, low income households dispose of fewer means for dealing with the consequences of a disaster. In general, these households are more inclined to reduce the consumption of basic goods such as food, health, and education after a catastrophe, which only ends up worsening their vulnerability. At the same time it is more likely that the poor live in precarious housing built in areas which suffer a greater risk of experiencing a natural disaster, which exposes them even more its to its consequences (Vakis, 2006; Fay et al. 2003; Pelham, 2011). As Valenzuela (2014) has argued, Chile has been much more successful at enforcing earthquake resistant construction norms than at enforcing urbanisation policies that prevent construction in locations that are likely to be affected by potential natural disasters.

In addition, lower income households respond differently to risks than higher income households: they are more averse to risk on an economic level, but exhibit risky behaviour in terms of their spatial orientation, in part due to lack of information about dangerous locations or because the benefits of such a location are perceived to be greater than the associated risk of a natural disaster occurring (Fay et al. 2003). This type of risk can be prevented through an appropriate policy of urbanisation that prevents construction in areas that are exposed to natural disasters.

The measures that can be taken to mitigate the impact of natural disasters on households, particularly low income ones, are varied. Building codes for the construction of new buildings and the supervision of compliance with them is at the heart of any mitigation strategy. The continuous improvement of existing buildings is equally important, as is the establishment of a social protection system that includes measures to confront the effects of natural disasters on different population groups (Fay et al. 2003; Spence, 2004). As Pelham, Clay and Braunholz argue, natural disasters must be considered in the context of the development process, and not as an exogenous event (Pelham et al. 2011). 
However, it is also the poor who require the most time to recover after a natural disaster, in part due to their own lack of resources, but also because of a lack of better public policy that focuses on their needs (Fay et al. 2003).

Vakis (2006) argues that a system of social protection must be considered as an integral part of any risk management strategy. In this context, a social protection system can be complementary to and synchronised with other emergency response mechanisms, as well as constituting a pre-existing system, which can be adapted to the occurrence of unexpected natural disasters, and which has the capacity to coordinate efforts from the public, non-public, and private sector. Such a system must also be based on a system of analysis and information that allows policymakers to identify clearly the risks to which a particular population is subjected, as well as serving as part of a strategy that manages emergency situations.

Most important among the instruments used to ensure social protection in the face of natural disasters are monetary transfers. These give households a degree of flexibility in terms of how they spend their resources as well as being relatively easy to administer, especially if compared with the distribution of actual basic goods (Vakis, 2006).

Along the same lines, Pelham et al. (2011) suggest social safety nets as a way of confronting natural disaster driven risk. The safety nets consist of a containment mechanism, but must be instituted before the disaster with clear procedures, that are integrated with the more general social protection system that should consist of unconditional transfers of goods or money, and are activated in the case of a natural disaster, especially to protect the most vulnerable households. Such mechanisms fulfil an expost role by helping to contain the effects of a natural disaster, but also an ex-ante role in that they can help reduce the risks to which low income households are exposed. Pelham et al. cite different countries that have implemented safety nets in different ways depending on their particular contexts: for example, in Bangladesh response mechanisms to floods and cyclones are pre-planned, and the management of this risk is completely integrated with the economic and policy structure of the country. Similarly, in Ethiopia, an expandable safety net has been established, which has some permanent mechanisms that protect the poorest households on a continuous basis, but that can easily be scaled up if the risk of a natural disaster increases. As we will examine in more detail in the research that follows, the Chilean government lacked such a system and consequently found it difficult to respond adequately to the emergency. 
The impact of such measures depends greatly on the type of natural disaster as well as on a timely identification of those groups of the population who would be the most exposed to a particular type of risk. However, most importantly, the success of such an initiative depends on the political will behind such a measure (Pelham et al, 2011).

Another instrument used to mitigate the effects of natural disasters is the institution of emergency employment programmes, which generally provide unskilled workers with temporary employment opportunities, often in the construction or reconstruction sector. These programmes have the added virtue of aiding the reconstruction process after a natural disaster, and act as a countercyclical measure. They are also flexible and relatively easy to implement (Vakis, 2006).

Project based competitive funding is another option that can help address the consequences of natural disasters that has several advantages: this funding is flexible and innovative, it can be deployed quickly, its administration is relatively simple and autonomous, it represents an opportunity to coordinate community organisations and local community leaders with governmental and non-governmental agencies, as well as ensuring citizen participation, and presenting an opportunity for creating employment for members of the community (Vakis, 2006). However, the application and selection procedures for this type of funding have to be simple, effective, and transparent to ensure their feasibility as a rapid response mechanism to a natural disaster.

In Chile, the social policy response to the earthquake did not really follow these international guidelines. While the government did institute some minimal employment programs, as well as microcredit programs for fishermen in the coastal areas, one of the principal tools through which it allocated reconstruction aid was through a mechanism called the Ficha de Proteccion Social (FPS, the Social Protection Form), which is based on principles of targeted rather than universal benefits, and generally does not contemplate the option of cash transfers.

The origins of the FPS relate to the many ways in which Chile's neoliberal military regime reduced the role of the state, in part by privatising social security provisions. This eliminated any aspiration to establish universal social rights that previous governemts had (Borzutzky, 2002; Solimano, 2012; and Illanes and Riesco, 2007). The replacement of social security systems that shared risk among their beneficiaries with privatised systems and minimal state guarantees was accompanied by the concept of rigourous targeting: those individuals not covered by the new privatised social policies would receive a 
minimum level of benefit from the state. ${ }^{8}$ To determine whether an individual was eligible for a potential benefit, a social worker would visit the household to undertake a survey of its general situation, called a Ficha CAS, which would translate a household's level of need into a point score. Based on this score, benefits would be assigned.

Since then the Ficha CAS has been replaced by a more modern version called the Ficha de Proteccion Social (FPS, the Social Protection Form), which takes into account a household's capability to generate income (Herrera et al., 2010). The FPS no longer focuses on unfulfilled basic needs relative to a minimum standard (e.g. the materials and quality of housing, whether a household possesses a television, refrigerator or telephone, and who is employed and the income level of the family), but instead asked questions about the number and age of family members, their educational level, and their employment situation in order to calculate an overall point score that expresses the level of economic risk to which a family is exposed as well is its ability to confront such risks. This new conceptualisation of poverty is considered more dynamic than previous measures, and theoretically is based on the capability approach (Herrera et al., 2010).

Whatever the criticisms of such a mechanism for targeting social policies may be (and there are many), a mechanism such as the FPS most certainly is not an appropriate tool for allocating benefits in the wake of a natural disaster. However, in the years following the 2010 earthquake, the FPS became one of the main social policy instruments used to deal with the consequences of the earthquake and tsunami. This method contrasts sharply with the recommendations for universal benefits made by the international literature, which is discussed above. However, in the absence of a social policy infrastructure specifically designed for dealing with the consequences of natural disasters, the consensus among policymakers in Chile at the time was to use established policy instruments for dealing with the reconstruction process, rather than experimenting with new and untested policies.

However, in public discussions of the reconstruction process, it also became clear that policymakers responsible for the reconstruction process never questioned the decision to apply policy tools designed for the allocation of social benefits under normal circumstances in a disaster situation. It is in these discussions were the impact of decades of viewing the state as a subsidiary provider of last resort

\footnotetext{
${ }^{8}$ In addition to being targeted, these benefits were also restricted in their number, which created a system of "cupos" (roughly translated as a quota). Potential beneficiaries had to apply for benefits and would be put on a waiting list to receive them. If a cupo did not become available for them, they would not receive the benefit, thus waiting indefinitely.
} 
becomes clear: public policy experts become so used to established patterns of policy-making and benefit allocation, that they do not question these patterns. In particular, this means that public solutions to private issues are generally not considered, or only considered as a measure of last resort. ${ }^{9}$

In fact, the only self-criticism that policymakers put forward during interviews and at public events with regard to the reconstruction process was that they had generated unrealistically high expectations among the population affected by the disaster by promising rapid and efficient solutions to housing problems, which they were then unable to deliver. ${ }^{10}$

\section{The impact of the earthquake on well-being and the standard of living of the affected population}

Understanding both the long-term and short-term impact of the 2010 earthquake and tsunami on the affected regions in Chile has not been an easy task. Affected communities had a difficult time in the period immediately following the disaster with establishing precise statistics on the extent to which their material infrastructure (including private housing) had been damaged. Even more difficult was ascertaining the impact of the disaster on the labour market, on the population's health, and on other aspects of the social devastation of the earthquake has caused. As a result, different government agencies produced widely differing statistics on the damage caused by the earthquake, which in some cases were vastly inflated by the pressures exerted by local communities to declare the greatest possible extent of damage with the objective of obtaining the greatest possible share of reconstruction resources.

\footnotetext{
${ }^{9}$ This issue is discussed in detail by Atria et al. (2013). One example that the book gives is the fact that when policymakers began to think about reforming Santiago's bus system (which later became known as Transsantiago), they did not even consider the possibility of establishing a public transportation system, but instead worked with a fragmented private system in which multiple providers need to be regulated and monitored.

${ }^{10}$ This statement is based on a presentation made by the Undersectary of Housing, Andrés lacobelli, on the $27^{\text {th }}$ November 2012 during the third session of the Plataforma Regional para la Reducción de Desastres en Las Amércias (UNISDR) in Santiago. On 25th September 2013, Andres Gil Santa Cruz, at the time the oordinator of the National Reconstruction Programme, during a debate at the Universidad de Los Andes, made the same point. Neither of the two representatives of the government at the time in any way questioned the use of normal policy tools during a post-disaster situation.
} 
In fact, both the data on the disaster's original damage as well as subsequent data on the reconstruction process were so confusing that the Bachelet administration which assumed office in March of 2014 had to commission a special delegate, Paula Fortes, who was then charged with preparing a report on the state of the reconstruction efforts, as well as with generating a new roadmap for the reconstruction process going forward. The report concludes: "the official data available lack updating and correct referencing; the data is inconsistent, incomplete, and measurement standards differ within the same sector; multiple instruments exist that register damage, but that do not "converse" with each other, which results in differences between communal, regional, and national data that surpass any fluctuations that could be explained through statistical error" (Ministerio del Interior, 2014).

Given these statistical problems, we have used data from a specific survey, the Encuesta Post Terremoto $(E T P)$, which the Ministry of Social Development undertook in the regions of Valparaíso, Metropolitana, Libertador Bernardo O'Higgins, Maule, Bíobío y Araucanía, to understand the extent of the social emergency that the earthquake and tsunami generated. The EPT gathered data during May and June of 2010 from 22.456 households, which represents a subset of the sample surveyed by Chile's regular household survey, the Encuesta Casen. This makes the EPT a longitudinal survey with two applications, one in 2009 and another in 2010. The survey is representative both nationally and regionally.

Due to its design as a panel survey, the EPT allows us to analyse how the well-being of the population was affected by the earthquake and tsunami. Although well-being is a very broad concept, the survey includes many variables that enable us to study a broad range of issues, including those pertaining to the concept of multidimensional poverty. Here, we present data on housing, health, education, income levels and employment.

According to the information gathered by the EPT, one of the most dramatic consequences of the earthquake was the damage to and destruction of housing. According to the EPT, approximately $8.8 \%$ of the population living in the affected areas experienced either major damage or the complete destruction of their houses. In the three regions most affected by the earthquake, Libertador Bernardo O’Higgins, Maule y Bíobío, the percentage of people affected was even greater at $17.3 \%$. Predictably, the impact of the earthquake on the housing of low income households was the highest. On average, $12 \%$ of the households in the lowest income quintile lost their homes compared with $4.6 \%$ in the highest income quintile. The higher rate of damage among lower income households can partly be explained by the low quality and precariousness of the housing itself, and partly can be attributed to the fact that 
they are built in areas that are subject to greater risk. The earthquake left poorer households doubly affected: not only did they suffer greater damage, but they also have no resources of their own with which to confront the damage incurred. In addition, people with low income levels are not insured against the risk of earthquakes, and are therefore wholly unprotected in the face of a potential disaster. Another area in which the post-earthquake household survey showed a significant impact is mental health. The survey incorporated the Davidson Trauma Scale that measures both the symptoms and the severity of post-traumatic stress disorder in people who were affected by natural disaster. Even three months after the 2010 earthquake, 12\% of the population in the affected regions (based on the percentage of people who responded to the service module on psychosocial impact) suffered symptoms associated with post-traumatic stress. This percentage was again much higher in the three regions most affected, where it varied between one fifth and one fourth of the population. Post-traumatic stress was also more prevalent among people from lower income households, either because they were more affected by the earthquake in terms of its material impact, or because they are less likely to be treated for the symptoms.

The EPT also measured the effect of the earthquake and tsunami on the education of children in the affected regions. The measure used was whether or not the beginning of the school year was delayed until the $1^{\text {st }}$ of April. Delays affected $24.6 \%$ of schoolchildren in the six regions where the earthquake caused the most damage, a proportion that increases to $70 \%$ in the three regions that were most affected (Libertador Bernardo O'Higgins, Maule y Bíobío). It is interesting to note that schools in these regions were relatively equally affected by the earthquake, regardless of whether they catered to high or low income households.

If we look at the earthquake's effect on poverty levels, the EPT shows that between its two applications in 2009 and 2010, 10.5\% of households fell below the poverty line while $7.4 \%$ rose above it. This generated a net increase in poverty at the national level from $16.4 \%$ to $19.4 \%$, if we consider the population included in both rounds of the survey. However, there are two reasons why we should be cautious in interpreting poverty levels, first, because longitudinal data is less precise, and second, because the data compares the situations of households in November/December to April/May. This prevents us from isolating the effect of the earthquake on the income of individuals and households as these fluctuate with the seasons according to the level of activity in particular sectors of the economy, particularly agriculture and construccion. 
Despite these limitations, the survey provides us with valuable information regarding the characteristics of households that suffered poverty between 2009 and 2010. People who were poor at both moments in time to a large extent (41\%) were households headed by women with an average of 8.7 years of education. By contrast, households that were not poor when the surveys were taken were generally headed by men and averaged 10.6 years of education. ${ }^{11}$

If we analyse variables associated with the labour market, we can perceive important differences which explain why some households are more likely than others to fall below the poverty line. Households that overcame poverty between 2009 and 2010 increased their labour market participation from 1.14 to 1.68 workers on average, while people who fall below the poverty line present a decline in their participation rates from 1.74 to 1.14 . Following the same logic, households whose income levels did not change did not experience a change in their labour market participation.

From this brief overview, we can see that the earthquake and tsunami had a significant impact in the affected regions on many dimensions of the population's standard of living. First and foremost, was the material damage suffered in terms of housing and infrastructure (including hospitals and educational establishments). As the following section will illustrate, the government's social policies responded primarily to these issues. Effects such as loss of employment, lower labour market participation, increased poverty levels and the significant effects of psychological stress where not - or were barely addressed by public policies. As regards the loss of employment, there were, for example some minor employment programs (including some small microcredit programmes for fishermen, who had lost their boats), but the government mainly relied on the reconstruction effort itself to deal with the unemployment generated by the earthquake. ${ }^{12}$

\footnotetext{
${ }^{11}$ Sanhueza, Contreras y Denis (2011) analysed the effects of the earthquake based on a difference on difference methodology for five dimesions of well-being: education, health, housing, income an employment. They used the Alkire and Foster (2007) methodology to construct an aggregate indicator of multidimensional poverty focused on specific age groups (children, adults and the elderly). They found that the earthquake negatively affects children in terms of the aggregate multidimensional poverty levels of households, while older people are affected in the dimension of health.

${ }^{12}$ Issues of post-traumatic stress, even though the data shows that this is where the earthquake had a significant impact, were not addressed in any way by specific public policies.
} 


\section{Chile's Social Policy Reponses to the Earthquake: The response of a neoliberal, subsidiary state}

While the previous section described the multiple dimensions of the social emergency created by the 2010 earthquake and tsunami, this section will analyse the response of government institutions to the situation. This response can be divided into two phases: the first was the immediate response to the earthquake, and consisted principally of the distribution of emergency aid (water, food and fuel) as well as organising emergency housing shelters. The second phase began approximately one month after the emergency with the planning of reconstruction, which in the sphere of social policy dealt mainly with the re-establishment of schools and hospitals, as well as with the rebuilding of housing.

Despite the fact that Chile is a seismic country where people are generally quite well-informed about basic emergency protocols, the scale of the 2010 earthquake and tsunami was nevertheless unexpected, and the country proved to be ill-prepared in terms of its capacity to respond to its immediate consequences. Since communication facilities were interrupted, the affected regions were left in a state of complete uncertainty, as their local municipal administrations could not communicate with their staff, and were cut off from both regional and central government emergency institutions. As a result, there is a widespread consensus that the initial public response to the earthquake was both ad hoc and chaotic.

Our interviews with municipal and local officials illustrate this point: they were ill equipped to provide help in any systematic way and had to respond to the crisis spontaneously, prioritising the most urgent needs of the moment, so that during the first days people had to survive with their own and their community's limited resources.

One inhabitant of Constitución's Cerro O'Higgins stated that: "the earthquake was on the $27^{\text {th }}$ February, the mayor and one person from the municipality showed up on the $30^{\text {th }}$. Although they knew from the beginning what had happened to us, because the next day they listed the people who had died. But nobody came from the municipality to ask us what we needed, how we were, nothing. They arrived on the $30^{\text {th }} .113$

It was in this context that neighbourhoods and communities spontaneously organised themselves collectively, and organized meetings to attend the most urgent needs of the community, such as finding accommodation for people who had lost their houses, obtaining food, water, and basic supplies,

13 
enforcing security in the neighbourhood, or organizing meetings with the local authorities in the hope of accelerating the assignation of subsidies.

"At first it was every day, every day we met in the morning, in fact this is how I got to be a community leader ... where I felt more engaged, and began to talk about what could be done to fix things, what we were going to do, where... placing homeless people with the less afected neighbors, thinking about how to help children to cope with this situation." (Neighbour, Cerro O “Higgins) ${ }^{14}$

In terms of social participation, the EPT shows that $21.9 \%$ of heads of households in the Maule region, and $36.9 \%$ in the Bíobío region implemented collective strategies to deal with the problems generated by the earthquake and tsunami. This social capital became a very relevant factor in the process that organised the emergency response to the earthquake. However, local governments did not have the ability to capitalise on this level of grassroots organization, nor to engage it in a sustained dialogue or programme for action. ${ }^{15}$

Municipal officials, on the other hand, express their own helplessness in the face of the overwhelming disaster. One interviewee from the regional ministerial housing service (SERVIU), in charge of implementing housing reconstruction explained:

"That's why I'm saying, the subject of reconstruction, where we failed as a ministry and as a country, ... we don't have a protocol for this sort of stuff. Because sometimes the river floods, and everything collapses (queda la escoba), the volcano and everything collapses (queda la escoba), the tsunami and everything collapses (queda la escoba). I think that there is no protocol, so you have to act on the hop, and often acting on the hop takes a lot of time, because you have to start asking a lot of questions." 16 This view is echoed by officials from the central government, who expressed a similar level of overwhelm:

"I think that as a country we lack a logic of formal protocols. The whole thing worked on a case-by-case basis. Almost like if there was a good relationship between the mayor of the moment and the municipality's housing staff with the regional or central government, then everything worked well. In

14

${ }^{15}$ This comment is based on interviews with members of the Observatorio de la Reconstrucción of the University of Chile.

16 
other cases, if they didn't get on with whoever, then it didn't." (Representative of the Ministry of Housing, Santiago) $)^{17}$

In general terms, the municipal administration was the institution that organised the emergency response to the disaster, while the central government and its regional agencies took on a more active role in the reconstruction process, which basically consisted of housing and infrastructure reconstruction. Municipal officials interviewed in the city of Constitución stated that the most important work consisted of surveying the damage caused by the earthquake, distributing food and clothing, organising emergency housing, providing emotional support to neighbours, and even managing a makeshift morgue. Many people appreciated the rapid response of local officials, who often deferred their own needs in order to help affected neighbours first. The level of commitment of municipal officials in the emergency situation was highly valued, even when people described the lack of organisation in the response to the emergency during the first few days. The chaos is reflected in the comment of one municipal official from DIDECO (the Direccon de Desarrollo Comunitario), who said:

"Well, in reality, I could tell you about four or five functions that were clear, but at the same time they were also diffuse, because there was so much demand for everything and from everybody that things were difficult. For example, I can tell you specifically that during the first days even though I was in charge of education, the next day, I was in charge of the transitional morgue, or in charge of distributing water. I was also involved in distributing food. We ended up giving out 21,000 daily rations. ... I took on the job, I think, even though it didn't correspond to what I was supposed to be doing." ${ }^{18}$

The high demand for emergency housing, the shutdown of basic services, increased levels of insecurity and the generalised panic meant that municipal services were completely overwhelmed by the challenges of managing the situation. In addition, a lack of coordination and direction meant that many resources received from NGOs and international organisations often did not correspond to the immediate needs of the population, or did not reach the population in a timely manner due to the existence of an established protocol for emergency situations.

The confusion and helplessness at the municipal level was compounded by the fact that the earthquake occurred just two weeks before a change in government. Municipal officials complained that after the handover they lost their networks in the public administration: 
"Before the handover, you knew who to call. We all had networks that extended to other communities, and to the regional government. Even to people in Santiago. But when Piñera took over, everything changed. Many positions weren't even filled. You didn't know who to call to get anything done. It was a mess. All new people. And they were clueless. You have no idea how this slowed things down." (Municipal official in charge of planning) ${ }^{19}$

The qualitative evidence discussed here presents a dramatic situation: the only institution in charge of managing natural disaster risk as well is post-disaster emergency efforts in Chile is the ONEMI. From the perspective of the inhabitants of Constitutión, these emergency efforts were uncoordinated, ineffective and basically chaotic. In reality, the emergency was dealt with spontaneously by local actors. Once the immediate emergency situation had been overcome, the usual state institutions and instruments were used to administrate the reconstruction process. It is during this process that the need for a dedicated institutional infrastructure for post-emergency situations became clear.

For instance, one of the most complicated policy issues after the earthquake was the question of how to select the beneficiaries of the various reconstruction programs that were instituted, especially those related to housing destroyed by the earthquake and tsunami. This is where the discussion of targeted benefits in an emergency situation becomes very relevant as most of the programmes directed at the reconstruction of housing required the existence of an FPS, the household survey discussed in section 2 of this paper.

The first problem with this system of allocation was that not every household affected by the earthquake also had an updated FPS. And updating existing surveys or undertaking new ones is too time-consuming in an emergency situation where social services are already stretched to the limit in terms of their administrative capacity (assuming that this administrative capacity has not been destroyed by the earthquake). Yet one senior representative at the Ministry of Housing defended the use of the FPS by arguing that the majority of Chilean households have been interviewed for an FPS, so that this information was readily available:

"Many of these families didn't have an FPS, but the majority did. In Chile, there are about 5 million households 3.8 million of which are covered by the FPS. If you look at this by quintile, it's pretty obvious: the first quintile is almost fully fully covered by the FPS, almost 100\%, and after that the proportion declines. In the fifth quintile it's pretty low. ... The FPS wasn't really a limitation, because in the cases 
where people didn't have it, we worked on a case by case basis. It wasn't a limiting factor for us in getting to lower middle-class or middle-class families who did not have the FPS." 20

According to government sources, the allocation of housing through the FPS was complemented by other programs directed at households, which were not registered in the FPS system. However, in practical terms, families which had not applied for any form of state benefits or aid prior to the earthquake, had to overcome a series of obstacles to access reconstruction programmes. Many argued that the time period during which people could apply for housing subsidies was too short if you consider that many people who needed help were excluded from this process because they did not have a preexisting FPS. One employee from the municipal administration confirms:

"People would say: "I can't apply, I suffered damage but I was living with so-and-so", and that's where the problem happened with the FPS. They simply didn't have their own form. So they had no right or simply didn't go to the housing department so that they could analyse the state of their housing, and declare them inhabitable. From there you had to go to the SERPLAC (Regional Secretary for planification and coordination) so that they would emit a certificate of damage. So a lot of people didn't know what to do. Then they went back to housing with a certificate of inhabitability, they'd come here and say: "look, here I have my certificate of inhabilitability, but I can't apply....., By then the application deadline had passed, and that's when they'd find out that they had to go to the SERPLAC." (Municipal official from Constitución $)^{21}$

This administrative chaos is also reflected in the comments of the beneficiaries of the system:

"No, no, no. There were tons of people doing surveys, who came from the municipality and from the government, the definitely it was all completely disorganized. In the sector of La Poza, people know the benefit system, they know which doors to knock-on, they know what a DIDECO is. So there were people who knew how this worked and they moved very well, but there were loads of people who never in their life [applied for a benefit], who've always worked and have always bought stuff with their own efforts who didn't know anything. So they were abandoned" (Interview with the local coordinator of the MNRJMovimiento por una Reconstrucción Justa, Movement for a fair reconstruction) $)^{22}$ 
The complaints about the housing benefit programmes also extended to the question of whether the available resources were allocated fairly. One woman from Villa Verde, for example, said:

"For example there are lots of people who were left out, I know of two women, who are the same as me. They live off their wage and nothing else. And here you see quite a few people who have two cars. Here in our passage, hear my neighbours have two tremendous cars, stupendous. That is, you can tell they're not for this kind of housing, so how the hell did they end up here? She's a policewoman. I don't know how much a policewoman earns, she's really well off, and everyone looks at her thinking $\mathrm{mmmm} .{ }^{\prime 23}$

This qualitative appreciation of the allocation of funding coincides perfectly with the more rigourous analysis carried out of this topic by the Presidential Delegation for Reconstruction, which concluded: "the FPS became the main door through which beneficiaries could go to obtain support. In this context, innumerable reports from the affected population highlight the lack of rigour in its application. This situation has been recognised by the current government." (Delegación Presidencial, 2014)24

In addition, the circumstances of families change abruptly as a result of such a natural disaster. These changes can produce two different results: families can lose everything, including their jobs, which evidently deteriorates their point scores, and makes them more eligible for benefits. On the other hand very poor families who are assigned new housing may increase their point scores, simply because households have been split as a result of the earthquake leading to a situation where fewer families live in a single dwelling, but in which each household has much less disposable income. The latter situation can lead to the perverse result that a household is poorer after receiving a housing benefit than before. ${ }^{25}$ To prevent this from happening, the government decided to freeze point scores obtained through the FPS and maintain them at pre-earthquake levels. ${ }^{26}$

However, in addition to the problems relating to fairness of allocation, observers of the reconstruction process also highlight another complicated aspect of using an instrument such as the FPS for a postdisaster reconstruction process. They highlight that the FPS is an instrument that is applied by

23

${ }^{24}$ La ficha se transformó en la principal puerta de ingreso a beneficios y apoyo, en este contexto, innumerables relatos de la población afectada plantean la escasa rigurosidad en su aplicación. En la misma dirección esta situación ha sido reconocida por el actual Gobierno (Delegación Presidencial, 2014).

${ }^{25}$ http://www.eldinamo.cl/2012/01/24/ficha-de-proteccio/

${ }^{26} \mathrm{http}: / /$ www.biobiochile.cl/2011/04/30/fps-mideplan-congela-puntajes-y-conserva-indices-previos-alterremoto.shtml 
municipalities at the local level. One of the problems that they observed relating to its application is that municipal administrations tended to inflate the damage that their communities had incurred, as this would increase the funds they would receive from the central government from reconstruction. Members of the municipal administration would then use these funds to obtain political support from their voters, thus engaging in clientilistic politics that would exacerbate the lack of transparency and fairness in the allocation of funds. ${ }^{27}$

All of these problems introduce new criticisms regarding the effectiveness of the FPS as an instrument for evaluating the vulnerability of families, especially in the face of risk factors that are unexpected such as those of natural disasters, and brings us back to the recommendation of the international literature on disasters discussed above, which argues that monetary transfers are the most efficient instrument for ensuring the social protection of people affected by a natural disaster (Vakis, 2006).

Another weakness that must be mentioned in the context of the Chilean earthquake and tsunami is the lack of coordination between those institutions dealing with its impact, as well as the lack of empowerment of local institutions, both in terms of their actual capacities (quantity and professionialism of their staff) as well as their capability to make independent decisions (Mella, 2011). As discussed above, this process was compounded by the change of government in the middle of the emergency situation.

In the Constitución area, the inefficiency of the public administration in resolving the problems of reconstruction, which was compounded by the requirement to pass through an established filter for social policy targeting such as the FPS, contrasts sharply with the role that the private sector played in helping affected communities. In particular, the company Celulosa Arauco, which is one of the main forestry conglomerates in the Bío Bío region, participated in the reconstruction. Arauco was the main private funder of Constitucións reconstruction plan (Plan de Reconstrucción Sustentable), as has been documented in detail by Tironi (2014). However, Arauco only funded to the elaboration of the plan, while the government funded investment in reconstruction itself (Ministerio del Interior, 2014).

Neighbours, government officials and also Arauco employees recognize that the company played a fundamental role in the first post-earthquake attention. According to one of its employees, the company took a leading role in collecting the debris, brought food and appliances not only for its people but for

\footnotetext{
${ }^{27}$ Interviews with experts from the Observatorio de la Reconstrucción, Universidad de Chile. See also Delegación Presidencial, 2014. In
} 
the general population, donated land for the construction of new houses and worked closely with the municipal administration to respond to the first needs of the community. This support was highly valued by the residents but also originated some conflicts. For example, a piece of land was donated by the company under the condition that half of the houses built had to be for Arauco employees affected by the catastrophe, and the other half could be distributed among the rest of the neighbours. The difference between those who worked for Arauco and those who did not (in socioeconomic terms, as well as in lifestyle and custom) generated a series of problems of coexistence that remain until today. However, the help provided by Arauco also raised suspicions about their real interests among the community. Tironi, for example, relates the extent to which local residents were sceptical of the company's motives, which they considered to be a form of "image laundering" by a firm that had "ruined a once fine seaside resort"and caused widespread environmental devastation in the area (Tironi, 2014). In our interviews, one community leader from the El Dique sector argued:

"Yes, Arauco is mixed up in all this. ... If you look carefully, there are lots of things where Arauco has invested money, like in the football field ... that was built by Arauco who then gave it to the municipality. They're building a cultural centre, Arauco is also in on that one. They will begin to build a library, also Arauco. So there's a lot of stuff where Arauco is involved.... But in reality what they're interested in is the road, in expanding the road, making it wider for the transport of wood. We all know that that's the reality. Arauco's involved in that too. ${ }^{128}$

Other private or non-governmental organisations also participated in the reconstruction process and filled gaps in the public provision of goods. However, these entities acted independently, and dealt with those needs of the population that they considered to be more important. Among the most mentioned organizations are Un Techo para Chile (an NGO working on housing policies), Celco (a Wood and Pulp Plant belong to Celulosa Arauco), the Red Cross, some universities, and Desafío Levantemos Chile (an NGO directed by the businessman and philanthropist Felipe Cubillos) who personally spoke with neighbours of Constitución and offered quick solutions for specific problems. Respondents point out that private organizations in general had the ability to respond quickly and appropriately to the most pressing population needs, as opposed to the Government where the processes were delayed by bureaucracy and inefficiencies. 
"After a few telephone calls, I got hold of his number, I called him [Felipe Cubillos] quite a few times, like 11 times, he answered, he was in Pelluhue, okay he said, let's get together in such and such a place in Constitución. That's when I met him, we greeted each other and he said: "Which school was destroyed?" We went to see the school, which is the Enrique Donn school, and he said to me: "And where do we put a modular school?" And we went to the place, and after half an hour he said: "Okay this is where we put the modular school." ... Much quicker, that is, imagine, in half an hour and he decided all these things.... And after that it's a well-known story. On 27 April, if I remember correctly, around that time they inaugurated the modular school, with a capacity for 1000 students, because Felipe understood that if the the children had a place to go to, where they could eat and be looked after during the whole day, it would give parents the chance to rebuild their house, get rid of the debris etc etc." (Municipal official, formerly in the Dideco division) ${ }^{29}$

In summary, the qualitative evidence produced by our field work in Constitución allows us to track the development of the institutional response of different levels of government in the face of the disaster: at first, there was a delayed response from both local and regional institutions. Once these institutions began to act, their actions were uncoordinated, ad hoc, and generally demonstrated a degree of overwhelm that is indicative of the extent of the disaster. The problems of institutional coordination were compounded by the effects of the change in government, and also affected negatively the subsequent allocation of social benefits, particularly in the area of housing and local reconstruction.

\section{Conclusions}

Before drawing conclusions about the Chilean government's response to the 2010 earthquake and tsunami, we should emphasise how difficult it is for governments to respond to natural disasters of this magnitude. Even developed countries would have suffered severe consequences and struggled with such circumstances. The experience of the United States with hurricane Katrina in 2005 illustrates how difficult it is to cope with natural disasters, both in terms of the immediate disaster response and the subsequent reconstruction process. ${ }^{30}$ Given the magnitude of the 2010 earthquake and tsunami, we

29

${ }^{30}$ Subell and Leeson (2006), for instance, highlight how federal, state and local institutions struggled with the reconstruction after Katrina. 
must conclude that Chile is very well prepared for natural disasters in terms of preventing material damage. The establishment and effective enforcement of appropriate earthquake resistant building codes meant that Chile's infrastructure and housing generally held up very well during the earthquake. This illustrates the strength of Chile's institutions and the capacity of the state for regulating and enforcing legislation when political will and attention is directed towards a particular issue. This is a very important conclusion as the policies that prevent material damage save lives and also contain the social emergencies that follow a natural disaster.

However, Chile is much less well-equipped for dealing with the slower and more time-consuming reconstruction process that follows a natural disaster. Probably the only exception to this rule is the state's efficiency in reconstructing public infrastructure, in particular as it relates to transportation (airports, ports, and roads) and utilities (water, electricity, and fuel supplies). The state is much less efficient, however, at urban reconstruction as it relates to both individual housing and urban renewal or planning.

The institutional structures that complicate such a reconstruction process relate first to the way in which the Chilean state itself is organised, and second to the way in which it structures social policy.

Regarding its organisation, the post-disaster coping strategies highlighted two important aspects of the Chilean state: first, accounts of how local institutions coped with the earthquake and subsequent reconstruction process illustrate that they are ill-equipped for dealing with an emergency at the local and regional level as they are not empowered to act independently of the central government, and also lack independent resources.

Second, the complications generated by a change in the central and regional governments during the period immediately following the earthquake illustrate the need for a permanent and independent civil service structure. At present civil servants in leading positions at all levels of government, but even more particularly so at the local and regional level, are appointed according to political criteria, and often also according to the role they played in the most recent local elections, rather than according to their actual capacities and administrative experience and capability (Sehnbruch and Siavelis, 2014). A change in government therefore breaks the hierarchical order and command structure within and between different levels of government as the new authorities usher in their own political appointees. As the evidence from the qualitative interviews showed, the negative consequences of such a situation in a reconstruction process significantly slow things down. 
Over the long term, however, the success of a post-disaster reconstruction process depends on the ability of the state to administer reconstruction funds through its regional and local administrations. It is here that we can observe the biggest contrast between the expectations of the population and the state's ability to deliver. From the qualitative interviews cited during the course of this paper, we can clearly observe that the Chilean population expects the state to help individual families overcome the consequences of a natural disaster. Thus, the people interviewed for this paper expected the state to provide alternative housing, funds for reconstruction, as well as other benefits in the shape of either monetary transfers, employment, or the delivery of emergency rations of food and water. This means that the population expected public rather than private help. In the cases where private help was forthcoming, local residents contrasted its delivery positively with the slower and more cumbersome arrangements made by local administrations.

It is in this slower and time-consuming reconstruction process that Chile's inability to respond adequately to the social policy emergency generated by any natural disaster must be highlighted: first, some social problems, such as reduced labour force participation, increased unemployment and poverty levels, as well as the more complex need for post-disaster psychological support were simply ignored or left unaddressed by public policy. This created a general sense of deprivation among the population that compounded the problems associated with the material loss of housing.

Second, the fact that the state used established mechanisms for benefit allocation in those social policy areas where it did intervene points to a lack of institutional preparation and planning for social emergencies.That these mechanisms were furthermore based on the idea of targeted social policy despite the emergency situation illustrates the extent to which the Chilean state still functions according to the logic established by a neoliberal regime many decades ago. In particular, this logic ignores the fact that not only the poor are vulnerable in a natural disaster situation. Higher income groups, in particular Chile's emerging middle class is equally vulnerable. Yet the targeted approach to reconstruction benefits by definition excludes the middle class.

That public officials did not question the logic of targeting resources in a post-disaster situation shows that this logic has become part of the government's DNA. This also explains why the Chilean state has not invested in expanding and preparing its institutions at all levels for a potential social emergency, and why it has not established an alternative regime for allocating social benefits in an emergency situation. 
This kind of institutional arrangement has historically never existed in Chile: as we saw above, while the state has invested in enforcing strict earthquake resistant building codes, it has never had the capability for adequately dealing with the reconstruction process that must follow a natural disaster. So while we are dealing with an atrophied state that was born out of a neoliberal legacy, we are also dealing with a modern state that has not invested adequately in its own development. The expectations of the Chilean population therefore significantly outpaced the capabilities of the Chilean state.

Some important and urgent lessons must therefore be learned from the 2010 earthquake and tsunami, particularly because the same mechanisms for allocating reconstruction benefits that were described in this paper have again been used following the 2014 earthquake and tsunami in the northern region of Iquique, which registered 8.2 on the Richter scale and displaced 80,000 people. Evidence from interviews carried out by the Observatory of Reconstruction indicate that the affected population is experiencing the same level of administrative confusion and delays in the reconstruction process as the population of Consitución did in the years following $2010 .{ }^{31}$

A future social policy infrastructure for natural disasters should consider the recommendations made by the international literature, which as a first emergency response suggests establishing cash transfers for victims of natural disasters that can be disembursed rapidly. A second level of institutional response must focus on preventing poverty and falls in the employment participation rate. This means organising the reconstruction effort with labour force participation in mind, and not simply leaving the allocation of jobs to the markets, which particularly affects women, who often leave the labour force following an emergency situation and do not want to work in reconstruction.

A third level of institutional infrastructure must deal with the material destruction at the household level. Procedures for reconstruction grants and loans should be simplified: a single certificate of damage should automatically entitle households to benefits rather that the endless bureaucratic procedures that currently characterise this process.

In addition to considering the institutional post-disaster infrastructure, the Chilean government should also consider how earthquake insurance can be expanded to middle class and low-income households.

\footnotetext{
${ }^{31}$ Interview with experts from the the Observatorio de la Reconstrucción of the University of Chile.
} 
Insurance should be compulsory and state backed for all households, and not just for those which have taken on private mortgages.

That Chile has the capability to establish better post-disaster institutional infrastructure is evident from the fact that the country has successfully implemented and enforced strict earthquake resistant building codes. The same institutional effort should now go into setting up a better procedures for postemergency and reconstruction process is. 


\section{A note on the fieldwork undertaken for this paper}

The interviews for this paper were undertaken in the city of Constitución(VII Region), which was selected because of the extent of the damage that the city experienced as a result of both the earthquake and tsunami due to its coastal location. Most of these interviews were carried out in Constitución itself during 2013 by the Reconstruction Observatory (Observatorio de la Reconstrucción) established the University of Chile.

\begin{tabular}{|l|l|l|l|}
\hline Interviewee & Number & Location & Date \\
\hline $\begin{array}{l}\text { Interview of housing ministry representative } \\
\text { with a high level of responsibility }\end{array}$ & 1 & Santiago & Mayo, 2014 \\
\hline $\begin{array}{l}\text { Interview of research are specialised on the } \\
\text { subjects of Reconstruction and urban planning }\end{array}$ & 1 & Santiago & Mayo, 2014 \\
\hline $\begin{array}{l}\text { Interviews with neighbours and community } \\
\text { leaders }\end{array}$ & 11 & Constitución & 2013 \\
\hline $\begin{array}{l}\text { Interviews with representatives from the } \\
\text { municipal administration }\end{array}$ & 2 & Constitución & 2013 \\
\hline $\begin{array}{l}\text { Interviews with representatives from regional } \\
\text { government agencies (SERVIU, SERPLAC) }\end{array}$ & 2 & Constitución & 2013 \\
\hline $\begin{array}{l}\text { Interview with representative of a large } \\
\text { company in the region }\end{array}$ & 1 & Constitución & 2013 \\
\hline TOTAL & $\mathbf{1 8}$ & & \\
\hline
\end{tabular}




\section{References}

- Albala - Bertrand, J.M. (1993). "Natural Disaster Situations and Growth: A Macroeconomic Model for Sudden Disaster Impacts". World Development, Elsevier, vol.21(9), pages 1417-1434, September.

- Alkire, S. and J. Foster. (2007). "Recuento y medición multidimensional de la pobreza". OPHI Working Paper 7, University of Oxford.

- American Red Cross (2011). "Report on the 2010 Chilean Earthquake and Tsunami Response". Open File Report 2011-1053.

- $\quad$ Arteaga, C., S. Pérez and A. Ugarte (2014) “Neoliberalismo, Subjetividades y Vulnerabilidad: La Experiencia Chilena en Desastres Socionaturales". Manuscript draft.

- Atria, F., G. Larraín, J. Benavente, J. Couso and A. Joignant (2013) "El Otro Modelo: Del Orden Neoliberal al Régimen de lo Público", Santiago: Debate.

- Birkland, T. (1996). "Natural Disasters as focusing events: policy communities and political response". International Journal of Mass Emergencies and Disasters; August, 1996, vol.14, n², pp 221-243.

- Bitar, S. (2010). “Doce lecciones del terremoto chileno". Estado, Gobierno y Gestión Pública, Revista Chilena de Administración Pública, n 15-16 (2010), p. 7/18.

- Borzutzky, S. (2002) "Vital Connections: Politics, Social Security, and Inequality in Chile", Notre Dame: University of Notre Dame Press

- CEPAL, (2010)a. "Terremoto en Chile, una primera mirada al 10 de Marzo de 2010". Naciones Unidas: Santiago de Chile.

- CEPAL, (2010)b. "Recomendaciones para una estrategia de reconstrucción y recuperación del terremoto de Chile del 27 de Febrero de 2010". Naciones Unidas: Santiago de Chile.

- Davis, A. (1996). "Targeting the vulnerable in emergency situations: who is vulnerable?", The Lancet, vol.348, September 28, 1996.

- Dore, M. H, and D. Etkin, (2000). "The importance of measuring the social costs of natural disasters at a time of climate change". Australian Journal of Emergency Management 15(3): 4651

- Cavallo, E. and I. Noy (2010). "The Economics of Natural Disasters: A Survey". IDB Working Paper Series No. IDB-WP-124.

- Delegación Presidencial para la Reconstrucción, Forttes, P. (2014). “Diagnóstico Estado de la Reconstrucción, Terremoto y Tsunami 27 de Febrero de 2010". Ministerio del Interior, Chile.

- Fay, M., F. Ghesquiere and T. Solo (2003). "Natural Disasters and the Urban Poor". En Breve, October 2003, $\mathrm{N}^{\circ} 32$. World Bank. 
- Gobierno de Chile, (2011). "Reporte de cumplimiento de la reconstrucción del terremoto del 27 de Febrero del 2010". Unidad Presidencial de Control del Cumplimiento, División de Coordinación Interministerial, Ministerio Secretaría General de la Presidencia.

- Gobierno de Chile, (2012). "Reporte de cumplimiento de la reconstrucción del terremoto del 27 de Febrero del 2010". Unidad Presidencial de Control del Cumplimiento, División de Coordinación Interministerial, Ministerio Secretaría General de la Presidencia.

- Herrera, R., O. Larrañaga and A. Telias (2010) "La Ficha de Protección Social”, in O. Larrañaga and D. Contreras, Las Nuevas Políticas de Protección Social en Chile, Uqbar Editores

- Hideki, T. and M. Skidmore, (2007). "Economic Development and the Impacts of Natural Disasters," Economics Letters, Elsevier, vol. 94(1), pages 20-25, January.

- Hochrainer, S. (2009). "Assesing the Macroeconomics Impacts of Natural Disasters, Are There Any?", Policy Research Working Paper, 4968. The World Bank.

- Hoffman, S. and A. Oliver Smith, (2009). "The Angry Earth: Disaster in Anthropological Perspective"

- Illanes, M.A. and M. Riesco, (2007). "Developmental Welfare State and Social Change in Chile", part of multiregional research program "Social Policy in a Development Context" by United Nations Research Institute for Human Development.

- $\quad$ ILO (2010). "Proyecto Impacto del Terremoto sobre el Empleo, Informe Final". OIT, Santiago de Chile.

- INE (2011). "Empleo Trimestral. Boletín de indicadores mensuales". Edición n 149, 31 de Marzo de 2011.

- Kovacs, P. (2010). "Reducing the risk of earthquake damage in Canada: Lessons from Haití and Chile". ICLR Research Paper Series, number 49. Institute for Catastrophic Loss Reduction.

- Larrañaga, O. and R., Herrera (2010). “Encuesta Post Terremoto: Principales resultados Efectos en la calidad de vida de la población afectada por el terremoto/tsunami”. Ministerio de Planificación, Gobierno de Chile y PNUD.

- Lindell, M. and C. Prater (2003). "Assessing community impacts of natural disasters". Natural Hazards Review, November 2003.

- Mella, M. (2012). "Efectos sociales del terremoto en Chile y gestión política de la reconstrucción durante el gobierno de Sebastián Piñera (2010-2011)". Revista Enfoques, vol. X, n 16, p. 19/46

- MINVU, (2010). “Programa de Reconstrucción de la Vivienda, ¿cómo postular a un subsidio de reconstrucción?". Gobierno de Chile.

- Pelham, L., E., Clay and T., Braunholz (2011). "Natural Disasters: What is the Role for Social Safety Nets?". SP Discussion Paper, $n^{\circ} 1102$, Social Protection and Labour, The World Bank.

- Raddatz, C. (2009). "The Wrath of God: Macroeconomic Costs of Natural Disasters", World Bank, Policy Research Working Paper No. 5039. 
- Rasmussen, T. (2004). "Macroeconomic Implications of Natural Disasters in the Caribbean", IMF Working Paper, WP/04/224.

- Sanhueza, C.; D. Contreras and A. Denis (2011) "Terremoto y sus Efectos sobre el Bienestar: un análisis multidimensional". Documento de Trabajo, UDP.

- Simmons, J. (Forthcoming). "Society Reconstruction: Popular Organizations in Post-Earthquake Concepción", Latin American Perspectives.

- Solimano, A., (2012) "Chile and the Neoliberal Trap: The Post-Pinochet Era", Cambridge University Press, Cambridge.

- Spence, R. (2007). "Risk and Regulation: Can Improved Government Action Reduce the Impacts of Natural Disasters?" Building Research and Information, 32:5, 391-402.

- Subell, R. and P. Leeson (2006) “Government's response to Hurricane Katrina: A Public Choice Analysis", Public Choice (2006) 127: 55-73.

- Tironi, M. (Forthcoming). "Disastrous Subjects: Catastrophes, Liberalism and the Parasitic Logic of Public Participation".

- United Nations, (2002). "Countering Disasters, Targeting Vulnerability". ISDR, Inernational Strategy for Disaster Reduction.

- Vakis, R. (2006). "Complementing Natural Disasters Management: The Role of Social Protection". Human Development Network, World Bank.

- Valenzuela Levi, N. (2011). “Localización Residencial, Desigualdad en el Ingreso y Gestión de los Subsidios Habitacionales para la Reconstrucción: ¿Cómo Generar Mayor Acceso a Oportunidades Mediante las Políticas de Vivienda?". Tesis País 2011, pp. 68-94. Fundación para la Superación de la Pobreza.

- Vargas, J. E. (2002). Políticas públicas para la reducción de la vulnerabilidad frente a los desastres naturales y socio-naturales (No. 50) (p. 48). Santiago de Chile: Cepal. 